УДК 902.3; 94(38) "-323/-146"

DOI: $10.18384 / 2310-676 \mathrm{X}-2019-5-200-208$

\title{
THE TERRACOTTAS OF KALLATIS - THE MASTERPIECES OF THE HELLENISTIC COROPLASTERS
}

\author{
T. Odobescu \\ Museum of archaeology "Kallatis" \\ 23 Sos. Constanța, Mangalia 905500, România
}

\begin{abstract}
This paper sets out to describe and characterize the terracotta production in the ancient Greek city of Kallatis located in the territory of modern Romania. Many of the figurines found here reflect the high level of the development of applied art, which was achieved by this Dorian colony in the second half of the 4th - early 3rd centuries B.C. The author summarizes and classifies almost all the finds of terracotta and also shows the role played by Kallatis in the production and distribution of these products typical of the ancient Greek world. The emergence of artistic workshops in the western Pontic cities was analyzed as a necessity for the newcomers to continue their traditional religious practices, to surround themselves with the faces of the gods that protected them, from birth to beyond the grave. The paper presented the synthesis and cultural osmosis processes, the interferences and the specific tastes of a province that had its own workshops and multiple clients, comparable to that of a metropolis. The conducted analysis confirmed that a large number of discovered terracotta, the remains of a ceramic furnace and other finds indicate the existence in the city of a wide local production of figurines, such as Tanagra - masterpieces of Hellenistic coroplasters.
\end{abstract}

Keywords: Dorians, terracotta figurines, Tanagra, Hellenistic coroplasters

\section{ТЕРРАКОТЫ ИЗ КАЛЛАТИСА - ШЕДЕВРЫ ЭЛЛИНИСТИЧЕСКОЙ КОРОПЛАСТИКИ}

\author{
Одобеску T. \\ Музей археологии «Каллатис» \\ 905500, г. Мангалия, шоссе Констанцы, д. 23, Румыния
}

\begin{abstract}
Аннотация. Целью статьи является описание и характеристика терракотового производства в древнегреческом городе Каллатис на территории современной Румынии. Множество обнаруженных здесь статуэток отражают высокий уровень развития прикладного искусства, которого достигла эта дорийская колония во второй половине IV - начале III в. до н.э. Автором обобщены и классифицированы практически все находки терракот, а также показана роль, которую сыграл Каллатис в производстве и распространении этих характерных для древнегреческого мира изделий. Было проанализировано появление художественных мастерских в западных понтийских городах как необходимость для вновь прибывших продолжать свои религиозные обряды, к которым они привыкли, окружать себя лицами божеств, которые их защищали, от рождения до загробного мира. Представ-
\end{abstract}

(с) СС ВУ Одобеску Т., 2019. 
лены процессы синтеза и культурного осмоса, помехи и специсические вкусы провинции, в которой были свои мастерские и многочисленная клиентура, сравнимая с метрополией. В результате проведённого анализа удалось доказать, что большое количество обнаруженных терракот, остатки керамической печи и другие находки свидетельствуют 0 существовании в городе широкого местного производства статуэток типа Танагра - шедевров эллинистической коропластики.

Ключевые слова: дорийцы, терракотовая статуэтка, Танагра, эллинистическая коропластика

The statues of burnt clay, exponents of Hellenistic coroplastic art, attracted the attention of researchers at the end of the $19^{\text {th }}$ century, almost a decade after the famous discovery of the necropolis of the Mycenaean city of Tanagra (Boeotia) in 1870 [7, p. $6-7 ; 9$, p. $412-424 ; 10$, p. $304-$ $306]$. At the beginning of the $20^{\text {th }}$ century, Vasile Pârvan announced the discovery of a coroplastic workshop and molds used for the production of ceramic idols: "In 1915 the whole ceramic workshop full of ancient molds was found in Kallatis, and it was possible for us to fill those molds with clay to reveal what types of figures they were used for. It is a rare case when we could appreciate the taste of the GreekRoman people of Scythia, who, out of all the molds found in the South, chose the ones from Kallatis. Unfortunately, during the war, this unexpected legacy was lost... " [17, p. 31; 18, p. 219].

The growing interest in the Kallatian terracottas after World War I translated to publications made by Th. Sauciuc Săveanu [20, p. 108-165], R. Vulpe [26, p. 329-339], O. Tafrali [25, p. 17-55] and later by a team of researchers from Mangalia Archaeological Museum [8, p. $85-98 ; 19$, p. 23-72]. Terracottas from the private collections received a better coverage, due to works published by V. Canarache [7].

A place containing numerous coroplastic fragments, called Monte Testaccio (by analogy with the famous hill in Rome also made of ceramic pieces [26, p. 336; 21, p. 299-339]) - a "mound", initially interpreted as "amphitheater" [20, p. 110; 25 , p. 17], was discovered. The impressive amount of coroplastic material, as well as the identification of the remains of a ceramic kiln $^{1}$ [7, p. 15-17] and of many molds, highlighted the existence of statuettes of Tanagra type at Kallatis in the $4^{\text {th }}$ $3^{\text {rd }}$ centuries B.C.

Hellenistic coroplasting, clay modelling of figurines, considered to be the most widespread category of miniature arts [10, p. 304], was present for a long period of time during the Hellenistic period, and reached its peak around 330-200 B.C., when the Tanagra style was dominating. The name of the style comes from the burial grounds of a city in Boeotia, known for an impressive number of ceramic figurines of the $1870^{\mathrm{s}}$, many of which came from the archaic and classical periods (mostly from the Hellenistic Period). Although they were discovered in the necropolis of the homonymous city of Boeotia, the place of origin of the "tanagras" is considered to be Athens [9, p. 412; $12 ; 13 ; 15]$. Certain ancient sources also mention the spread of these clay statues in antiquity, for example Pausanias (I, 2, 5) and Pliny the Elder (Nat. Hist., XXXV, 151-199).

The role of these terracotta statues can be deduced from the archaeological con-

${ }^{1}$ About the kilns founded in Callatis (Neptun) and Tomis [1]. 
text and from what the figurines represented. The statues were generally placed in tombs and sanctuaries, which attests to their votive and religious role. In the Hellenistic times some of the figurines depicted deities and heroes, but most statues represented secular figures. There were large, small and unique series pieces, sometimes reaching dimensions of 30-35 $\mathrm{cm}$ and even larger [5, c. 515-516], and were specially detailed, painted and finished.

Inspired by the statuary, the typological repertoire of the figurines was predominantly composed of female characters standing, draping, dancing, sitting or practicing archery. The distinctive feature is full naturalism, characteristic of the pieces from the last decades of the $4^{\text {th }}$ century B.C., particularly among those representing young women in chiton and himation, draped subtly and variedly, in graceful positions, in which the influence of Praxiteles art can be noticed. The coroplastic figurines discovered at Kallatis are an example of a superior craftsmanship, due to their portraiture, features, colour and finish. We must remember that the city was a colony of Heraclea Pontica, which, as the ancient sources show, was a colony of Megara and Boeotia.

From the point of view of the stylistic evolution, the following conclusions can be drawn: the copies from the $4^{\text {th }}$ century B.C. demonstrate a balanced composition, with the drape usually emphasizing the shape of the body, following the trend in the $3^{\text {rd }}$ century B.C. With time the posture became more relaxed, and the drapery started to exist separately from the body, with angular folds that formally contradict the body shape [14].

A topographic classification of the specimens of this style can be done ac- cording to the content of the clay, characteristic of the various regions of the Hellenistic world, and to some specific local features. The molds often point to the outskirts of the Greek world, because each city had its own workshop and a clientele similar in size to that of the metropolis. Some Hellenistic cities had area-based specialisation, including the neighbouring regions of Greece $[1 ; 2 ; 3 ; 4 ; 6 ; 16]$.

The essential novelty of making statuettes, derived from the Greek era, consisted in replacing the heavy process of modelling clay by hand with the process of their production using molds. The mold, which was at first a kind of seal, representing the front of the head, eventually extends to the whole body of the figurine, and was generally adopted around 350 B.C. The use of molds and the creation of statuettes of two or more parts, glued together, gave rise to a particularly rich and widespread production in many centres of the ancient world.

There was a talk about the universality [9, p. 387-426; 10, p. 305] of the Tanagra style, which resulted either from the actual spread of the products manufactured by the Boeotian workshops, or from the export of the molds, as well as from the free imitation of the typology and the re-export of the pieces or molds. At first, they spread only in the southern centres, but after the $330^{\text {s }}$ B.C., as the trade routes expanded, almost all African-Asian cities, islands, Mediterranean city-states and those on the Pontic coast started to produce molds themselves, developing their own ceramic industry. In Kallatis, for example, in the $3^{\text {rd }}$ century B.C., there were more beautiful terracotta statuettes than in the neighbouring Tomis, Histria, Odessos, Apollonia or Mesembria. Phanagoria had the same privileged posi- 

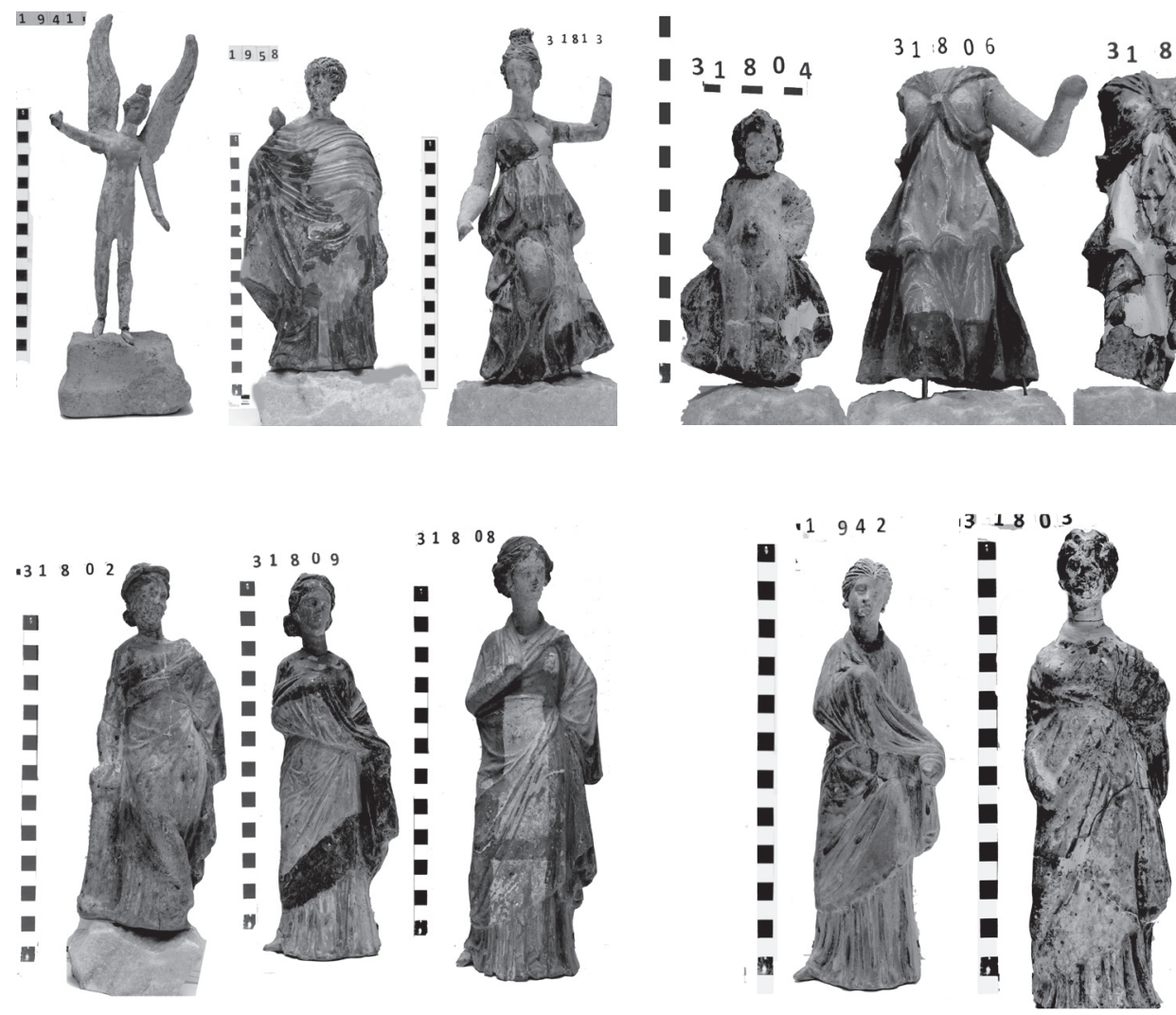

Puc. 1. Терракоты из Каллатиса.

tion among its neighbours from the north Pontic region [2].

The technique of making the statues, the same for the Hellenistic and Roman times, obviously, required a lot of skill and artistic sense. The processing of clay was a fundamental operation, because the production of such works was possible only when the quality of clay allowed it. In the process of making the terracotta statues, the clay was thoroughly chosen, washed, clarified and macerated, and supplemented with small pieces of burnt soil, sand and degreasers. In production of ceramic pots, shrinkage of the clay during firing is a favourable phenomenon for the vessel, whereas for statuettes it causes deformation and breakage, which leads to scratch- es. It is worth mentioning that there was an admirable clay soil and kaolin deposits near by the city of Kallatis [7, p. 21].

It was common to use separate molds to produce different parts of the statuettes, which were then assembled, finished manually, fired and finally painted. The backs of the figurines were often shaped, but sometimes were left smooth, with a burning hole.

In order to make terracotta resemble marble carvings it was covered with certain materials. The colour of the statues was rich and harmonious; unfortunately, being painted with tempera, and fixed only by a secondary firing it could only be conserved under special conditions. The origin and structure of some of the col- 
ours used was discovered: blue dye came from Egypt, obtained from copper silicate, red dye was derived from iron oxide, pink dye was obtained from mercury sulphide (cinnabar) [7, p. 26]. Noteworthy is the differentiation of colours used for rendering the human complexion: reddish brown was used for the representation of the male skin tone and white / pink / yellow for the female skin tone.

Speaking of the coroplastic studies, the $1960^{\text {s }}$ remain a turning point in the Romanian archaeological science, when the foundation of a comparative system of analysis was built, in which the data of stratigraphic, epigraphic, artistic sources were compared with the major statuary of Classical and Hellenistic Periods. A fundamental research was carried out, regarding the collection of terracotta statues from Histria, from the "Fisheries" point [22, p. 243-269]. They were discovered in 1963 and quickly got the attention of scientific circles. The statues were categorized by groups and subgroups, which exemplified the existence of several sets of molds; the main criteria of differentiation were the structure of the clay, the clothing and hairstyles, the position of the limbs, etc. Few years later, the only catalogue of Tanagra masks and figurines from the workshops at Kallatis was published, featuring the analysis of pieces from the private collections of Dr. Mircea Athanasiu (Bucharest), Constantin Baraschi (Bucharest), Ivanciu Bărăoanu (Constanta), Gabriela are analyzed. Bordenache (Bucharest), George Buzdugan (Bucharest), Vasile Canarache (Constanta), Vladimir Colin (Bucharest), Prof. Mircea Herovanu (Bucharest), Eugen Jebeleanu (Bucharest), Marcela Mirea (Bucharest), Gelu Naum (Bucharest), George Severeanu (Bucharest), Dr. Horia Slobozeanu, and artifacts from the collection of the Constanta Archeology Museum. The research was based on the typological criteria, thus nine distinct groups were outlined: I - molds; II - deities, heroes, mythological figures, III - ephebes and men figures, IV - women with veils, facial expressions, $\mathrm{V}$ - female heads and busts, VI whole statuettes, VII - headless statues, VIII - toys, portraits of children, children with animals, IX - theatrical masks, figures of actors [7, p. 18-19, 28].

In 1969, it appears, what was intended to be a Corpus (a complete scientific study) which brought together the ancient terracotta from the Maria and Dr. G.Severeanu collection of the History Museum of the city of Bucharest, was based on the classification of figurines from the centres of their production [11, p. 35-69], including two copies from Kallatis [11, p. 47, nr. 75, 76]. In recent years the studying the terracotta of Kallatis has continued, mostly dedicated to the terracotta from the province of Moesia Inferior from the $1^{\text {st }}-3^{\text {rd }}$ centuries A.D. [24, p. 216-223; 23].

In this paper, however, we did not intend to focus on the typological analysis of the terracotta figurines from the collection of Kallatis, as it was successfully covered by the authors mentioned above. We would like to draw attention to the fact that the pieces discovered in closed archaeological environments in the previous decades, that fall into the typological categories outlined by V. Canarache, which were accompanied by ceramic objects, appear to be a part of the funerary inventory of tombs of the Hellenistic Period. A remarkable example is the discovery made in 1981 [8, p. 85-98] of a funerary construction composed of two adjacent boxes made of limestone slabs, sheltering the skeletons of a man and a woman which were members of the same 
family. Such complexes are frequently found in the Greek and Hellenistic necropolis of the city of Kallatis and in those of other western Pontic cities. The exceptional value of the discovery, however, lies in the presence of thirteen imported terracotta statues, placed in the second box. They were created under the influence of the Attic statuary style, among which representations of deities such as Aphrodite, Eros, Nike, Dionysus can be found. The statues, which are themselves an artistic achievement, kept their colours perfectly preserved, and are among the best known examples to date in the Pontic space.

The terracotta statues of Kallatis, small masterpieces full of refinement, perfectly reflect the degree of development reached by the Dorian colony from the second half of the $4^{\text {th }}$ century B.C. to the beginning of the $3^{\text {rd }}$ century B.C., and demonstrate this colony's role in making and spreading these products, so characteristic of the Greek world.

Статья поступила в редакиию 23.08.2019

\section{ЛИТЕРАТУРА}

1. Кобылина М. М. Терракоты из г. Феодосии // Терракоты Северного Причерноморья / Отв. ред. М. М. Кобылина / Свод археологических источников. Вып. Г 1-11. М.: Наука, 1970. C. $78-82$.

2. Кобылина М. М. Терракотовые статуэтки Пантикапея и Фанагории. М.: АН СССР, 1961. $182 \mathrm{c}$.

3. Леви Е. И. Терракоты из Ольвии // Терракоты Северного Причерноморья / Отв. ред. М. М. Кобылина / Свод археологических источников. Вып. Г 1-11. М.: Наука, 1970. С. 33-56.

4. Шевченко А. В. Терракоты античного Херсонеса и его ближней округи. Симферополь: Наследие тысячелетий, 2016. 520 с.

5. Херсонес Таврический в третьей четверти VI - середине I в. до н.э. Очерки истории и культуры. Киев: Академпериодика, 2005. 625 с.

6. Дремсизова-Нелчинова Ц., Тончева Г. Антични теракоти от България. София: Български художник, 1971. 124 с.

7. Canarache V. Măşti şi figurine Tanagra din atelierele de la Kallatis Mangalia, Muzeul de Arheologie Constanța, 1969, 190 p.

8. Bârlădeanu Zavatin E. Statuete de teracotă dintr-un complex funerar descoperit la Kallatis // Pontica. 1985. № 18. P. 85-98.

9. Gramatopol M. Artele miniaturale în antichitate / Ed. Meridiane. București, 1991. 463 p.

10. Gramatopol M. Civilizaţia elenistică / Ed. Orientul latin. Braşov, 2000. 445 p.

11. Gramatopol M., Crăciunescu V. Les terres cuites anttiques de la collection Marie et Dr. G. Severeanu du Musée d'Histoire de la ville de Bucarest // Revue Roumaine d'Histoire de l'art (RRHA). 2015. № 2. P. 35-69.

12. Higgins R.A. Catalogue of the Terracottas in the Departament of Greek and Roman Antiquities, British Museum. Vol. I. Greek: 730-330 B.C. L.: British Museum, 1954. 432 p. with 208 plates.

13. Higgins R.A. Greek Terracottas. Methuen's Handbooks of Archaeology. L.: Methuen, 1967. 169 p., 30 text figures, 64 plates, 4 colour plates.

14. Kleiner G. Tanagrafiguren. Untersuchungen zur Hellenistischen Kunst und Geschichte. Berlin, 1942. $324 \mathrm{~s}$.

15. Mollard-Besques S. Les Terres Cuites Grecques. Paris: Presses Universitaires de France, 1963. 137 p., 32 planches d'illustrations en héliogravure et en couleurs.

16. Ogrenova-Marinova L. Terres cuites de Messambria, în Nessebre, în memoriam Jeannae Čimbuleva. Burgas, 2005. P. 51-91. 
17. Pârvan, V. Raport asupra activității MNA în cursul anului 1915 înaintat domnului ministru al instrucțiunii şi cultelor de directorul muzeului, București, 1916. P. 31-36.

18. Pârvan V. Începuturile vieții romane la gurile Dunării. Cultura Națională, 1923. 247 p.

19. Rădulescu A., Bărbulescu M., Buzoianu L., Cheluță-Georgescu N. Reprezentări figurate în aşezarea de epocă elenistică de la Albeşti // Pontica. 1995-1996. № 28-29. P. 23-72.

20. Sauciuc-Săveanu Th. Kallatis // Dacia. 1924. № 1. P. 108-165.

21. Sauciuc-Săveanu Th. Kallatis // Dacia. 1941-1944. № 9-10. P. 243-347.

22. Suceveanu Al. Depozitul de statuete romane de teracotă de la Histria // Studii și Cercetări de Istorie Veche (SCIV). 1967. Tomul 18. № 2. P. 243-269.

23. Ştirbulescu C. Teracote în provincia Moesia Inferior în secolele I-III. Cu specială privire asupra celor din Dobrogea romană. Universitatea București. Teză de doctorat, 2008. 389 p. (ms).

24. Szilágyi J.G. Späthellenismus in Kallatis. Civilisation grecque et culture antiques périphériques. Bucharest, 2000. P. 216-223.

25. Tafrali O. La cité pontique de Kallatis. Recherches et fouilles // Artă și Arheologie. 1927. № 1. P. 17-55.

26. Vulpe R. Deux terres cuites greques de Kallatis // Dacia. 1935-1936. № 5-6. P. 329-339.

\section{REFERENCES}

1. Kobylina M. [Terracottas from the city of Feodosia]. In: Terrakoty Severnogo Prichernomor'ya. Svod arkheologicheskikh istochnikov, ser. Г 1-11 [Terracotta of the Northern Black Sea. Arch of archaeological sources, iss. G 1-11]. Moscow, Nauka Publ., 1970, pp. 78-82.

2. Kobylina M. Terrakotovye statuetki Pantikapeya i Fanagorii [Terracotta figurines of Pantikapaion and Phanagoria]. Moscow, AN SSSR Publ., 1961. 182 p.

3. Levi E. [Terracottas from the city of Feodosia]. In: Terrakoty Severnogo Prichernomor'ya. Svod arkheologicheskikh istochnikov, ser. $\Gamma$ 1-11 [Terracotta of the Northern Black Sea. Arch of archaeological sources, iss. G 1-11]. Moscow, Nauka Publ., 1970, pp. 33-56.

4. Shevchenko A. Terrakoty antichnogo Khersonesa i ego blizhnei okrugi [Terracotta ancient Chersonesos and its near around]. Simferopol, Nasledie tysyacheletii Publ., 2016. 520 p.

5. Khersones Tavricheskii $v$ tret'ei chetverti VI - seredine I veka do n.e. Ocherki istorii i kultury [Chersonese in the third quarter of VI - the middle of I century BC, history and culture]. Kiev, Akademperiodika Publ., 2005. 625 p.

6. Dremsizova-Nelchinova Ts., Toncheva G. Antichni terakoti ot Bŭlgariya [Antique terracotta tiles from Bulgaria]. Sofia: Bŭlgarski khudozhnik Publ., 1971. 124 p.

7. Canarache V. Măşti şi figurine Tanagra din atelierele de la Kallatis Mangalia [Masks and figurines Tanagra from the workshops at Kallatis], Muzeul de Arheologie Constanța, 1969, $190 \mathrm{p}$.

8. Bârlădeanu Zavatin E. Statuete de teracotă dintr-un complex funerar descoperit la Kallatis [Terracotta statues from a funeral complex discovered in Kallatis]. In: Pontica, 1985, no.18, pp. 85-98.

9. Gramatopol M. Artele miniaturale in antichitate [Miniature art in antiquity]. Bucureşti, Meridiane, $1991.463 \mathrm{p}$.

10. Gramatopol M. Civilizația elenistică [Hellenistic civilization]. Braşov, Orientul latin, 2000. $445 \mathrm{p}$.

11. Gramatopol M., Crăciunescu V. [The ancient terracotta of the Marie and Dr. G. Severeanu collection of the History Museum of the city of Bucharest]. In: Revue Roumaine d'Histoire de l'art (RRHA) [Romanian Journal of Art History], 2015, no. 2, pp. 35-69.

12. Higgins R. A. Catalogue of the Terracottas in the Departament of Greek and Roman Antiquities, British Museum. Vol. I. Greek: 730-330 B.C. L.: British Museum, 1954. 432 p. 
13. Higgins R. A. Greek Terracottas. Methuen's Handbooks of Archaeology. L.: Methuen, 1967. $169 \mathrm{p}$.

14. Kleiner G. Tanagrafiguren. Untersuchungen zur Hellenistischen Kunst und Geschichte [Tanagra figurines. Studies on Hellenistic art and history]. Berlin, 1942. $324 \mathrm{s.}$

15. Mollard-Besques S. Les Terres Cuites Grecques [Greek Terracotta]. Paris: Presses Universitaires de France, 1963. 137 p.

16. Ogrenova-Marinova L. Terres cuites de Messambria, in Nessebre, în memoriam Jeannae Čimbuleva [Terracotta of Messambria, Nessebre, Memoriam Jeannae Čimbuleva]. Burgas, 2005. P. 51-91.

17. Pârvan V. Raport asupra activității MNA în cursul anului 1915 înaintat domnului ministru al instrucțiunii şi cultelor de directorul muzeului [Report on the activity of the MNA during 1915 submitted to the minister of instruction and cults by the museum director]. București, 1916, pp. 31-36.

18. Pârvan V. Începuturile vieții romane la gurile Dunării [The beginnings of Roman life at the mouths of the Danube]. Cultura Națională, 1923. 247 p.

19. Rădulescu A., Bărbulescu M., Buzoianu L., Cheluță-Georgescu N. [Representations depicted in the Hellenistic period settlement of Albesti]. In: Pontica. 1995-1996, no. 28-29, pp. 23-72.

20. Sauciuc-Săveanu Th. Kallatis. In: Dacia, 1924, no. 1, pp. 108-165.

21. Sauciuc-Săveanu Th. Kallatis. In: Dacia, 1941-1944, no. 9-10, pp. 243-347.

22. Suceveanu Al. [The deposit of Roman terracotta statues from Histria]. In: Studii și Cercetări de Istorie Veche (SCIV) [Studies and Researches of Old History], 1967, vol. 18, no. 2, pp. 243-269.

23. Ştirbulescu C. Teracote în provincia Moesia Inferior în secolele I-III. Cu specială privire asupra celor din Dobrogea romană. Universitatea București. Teză de doctorat [Terracotta in the province of Lower Moesia in the 1st-3rd centuries. With special regard to those from Roman Dobrogea. Bucharest University. Doc. sci. Thesis, 2008. 389 p. (ms).

24. Szilágyi J. G. Späthellenismus in Kallatis. Civilisation grecque et culture antiques périphériques [Späthellenismus in Kallatis. Greek civilization and ancient peripheral culture]. Bucharest, 2000. P. 216-223.

25. Tafrali O. [The pontic city of Kallatis. Searches and excavations]. In: Artă și Arheologie [Art and Archeology], 1927, no. 1, pp. 17-55.

26. Vulpe R. [Two Greek terracotta from Kallatis]. In: Dacia, 1935-1936, no. 5-6, pp. 329-339.

\section{ИНФОРМАЦИЯ ОБ АВТОРЕ}

Одобеску Татьяна - доктор искусствоведения, зав. отделом Музея археологии «Каллатис» (Мангалия, Румыния);

e-mail: tatianaodobescu@yahoo.com

\section{INFORMATION ABOUT THE AUTHORS}

Tatiana Odobescu - Doctor of Art History, head at the Department of the Museum of archaeology Kallatis, Mangalia, Romania;

e-mail: tatianaodobescu@yahoo.com 


\section{ПРАВИЛЬНАЯ ССЫЛКА НА СТАТЬЮ}

Одобеску Т. Терракоты из Каллатиса - шедевры эллинистической коропластики // Вестник Московского государственного областного университета. Серия: История и политические науки. 2019. № 5. Циркумпонтика. С. 200-208.

DOI: $10.18384 / 2310-676 \mathrm{X}-2019-5-200-208$

\section{FOR CITATION}

Odobescu T. The terracottas of Kallatis - the masterpieces of the Hellenistic coroplasters. In: Bulletin of the Moscow Regional State University. Series: History and Political Sciences, 2019, no. 5, Circumpontica, pp. 200-208.

DOI: $10.18384 / 2310-676 \mathrm{X}-2019-5-200-208$ 